ISSN 2409-2665

Journal of Logistics, Informatics and Service Science

Vol. 8 (2021) No. 2, pp. 1-18

DOI:10.33168/LISS.2021.0201

\title{
The Role of Visionary Leader Competency in Bridging Company's Levers of Controls and Dynamic Capabilities
}

\author{
Inta Hartaningtyas Rani ${ }^{1}{ }^{*}$, Lestari Adhi Widyowati ${ }^{2}$ \\ Ahmad Dahlan Institute of Technology and Business, Department of Accountancy, \\ South Tangerang- Banten, Indonesia \\ intahartaningtyas@itb-ad.ac.id
}

\begin{abstract}
The new normal in business world leads to business uncertainty and risks attached in each decision making. The success in implementing LoC that supports the creation of qualified company's dynamic capabilities cannot be separated from the role of a leader as a decision maker. This study is aimed at elaborating the results of previous research by explaining how visionary leader competency bridges the LoC and dynamic capabilities of the company as a novelty in this scientific study. The profiles of respondents in this study are firstline, middle and top managers of cross-industry companies in Indonesia. The questionnaire distributed consists of questions adopted from literatures. Hypothesis testing was done using structural equation model with SmartPLS 3.2.1 as a test tool. The results of testing the hypothesis of this study indicate that although there is a direct relationship between the effect of LOC on the company's dynamic capabilities ( $\mathrm{H} 1$ is accepted), the role of visionary leader competency in bridging this direct effect is not proven ( $\mathrm{H} 4$ is rejected). This is indicated by the magnitude of the indirect effect of LOC on dynamic capabilities mediated by the leader's visionary competency ( $p$-value of indirect effect) which is 0.306 exceeding 0.05 . It can be concluded that the visionary leader competency cannot be the only variable intervening the implementation of LOC to influence the company's capabilities. Instead, it must be equipped with competencies and other factors that synergize in the leadership style carried out by a leader.
\end{abstract}

Keywords: Dynamic capabilities, levers of controls, leader competency, strategic, visionary. 


\section{Introduction}

Perpetual disruption, which was accelerated by the Covid-19 pandemic and various crises that followed, is currently driving business conditions to heightened uncertainty and strategic risk. Strategic risk management requires a different approach from managing uncertainty. However, both are antecedents for determining priorities in choosing a control system which will ultimately have an impact on the effectiveness of the company's management control system itself (Simon, 1995). Companies must implement an optimal combination of levers of control (LOC) in accordance with the level of uncertainty and strategic risk faced. The control system, according to this notion, is made up of four elements: belief and boundary as a system, also diagnostic and interactive control model.

The four forms of control are believed to be a different control mechanism for management that is able to achieve a balance of creativity and corporate control (Spekle, et al., 2017). This becomes important where the new normal era demands the company's skills in carrying out business strategies so that they can successfully struggle and strive to improve their performance (thrive). To realize its objective to improve company performance, LOC must be able to support the formation of the company's ability to adapt to the uncertainty of business dynamics which was first coined by Teece (1994) as the company's dynamic capabilities. It is supported by the research conducted by Barreto (2010) stating that dynamic capabilities are a company's ability to tackle challenges in a systematic manner shaped by its tendency to recognize it in making the proper decisions and orientate. By having then increasing dynamic capabilities, company will be able to improve performance, maintain competitive advantage and have resilience through crises. Stakeholders are trained to collaborate, have comparable cognition about broad hazards, and at the very least know what operand and operant resources are available in their system that may be used to handle the unprecedented by having a model that is dynamic and fosters continuous learning (Miftah \& Hermawan, 2021).

In its implementation, dynamic capabilities are attached to innovation and fast decision making. As firstly stated by Adner and Helfat (2003), there is a cognitive role of decision makers and human capital in the dynamic capabilities' framework. Teece, Peteraf, and Leih (2016) more specifically explain especially during a crisis, The CEO's and top management's capacity to perceive the key of company's growth and then provide the right reaction to ultimately guide and direct the company moving forward is very important for the dynamic capabilities of the company. Visionary leaders with the competencies of being risk-taker, having business knowledge, being adaptable, having ability to visualize, being strategic and creative (Ann \& Gilley, 2005) allegedly meet the criteria that are able to optimize the company's dynamic capabilities. Although no research has been found to date that examines the relationship between the leader's visionary competency and the 
company's dynamic capabilities, the idea is in line with what is written in the research of Xin et al. (2020) stating that the visionary leadership style is the originator of the company's dynamic capabilities through its ability to create a unique corporate culture and strengthen the company's human capital. Helfat, et al. (2007) also believe that the quality of a transformational leader who is visionary, intellectually stimulating, and an inspirational motivator will reflect a leadership capacity that is better able to sense and seize opportunities, both of which are the components of the company's dynamic capabilities.

The concept of LOC, dynamic capabilities and their relation to the capacity of a leader as a decision maker is still being studied in recent studies. Teece himself, through his research, is still reviewing the framework of dynamic capabilities in relation to various indicators influencing each other. In 2016, along with Peteraf and Leih, Teece conducted a study entitled "Dynamic Capabilities and Organizational Ability: Risk, Uncertainty, and Strategy in the Innovation Economy", which examined the relationship between current conditions which are full of risk and uncertainty and how strong dynamic capabilities require a leader (human cognition) who is capable of carrying out the company's strategies that will be able to overcome the challenges faced. Especially with the focus on economic transformation for developing countries to get out of the middle-income trap (MIT), it takes movement from various business sectors to take appropriate and fast steps in executing current business strategies and as much as possible to avoid failures that can cause costs and lose company opportunities to survive.

With limited research on the importance of the role of visionary leader competencies in bridging the relationship between levers of control and dynamic capabilities of companies, this research will be a novelty in strategic management literacy especially in the fields of MCS, Leadership and corporate capabilities.

\section{Literature Review}

\subsection{Levers of Control (LOC)}

A management control system (MCS) is a management tool used to ensure the implementation of the company's strategy to achieve company goals. In its implementation, Simon (1995) identified a control system related to control over core corporate values, risks that must be avoided, and important variables of company performance as follows;

1. Belief systems are a set of definitions that are explicitly, formally and systematically communicated by top management as a form of basic values, goals and direction for the company. It can be in the form of a vision, mission statement or company belief to inspire and motivate employees in the creative process when exploring opportunities and creating shared values.

2. Boundary systems are formal systems that limit areas of strategic activity that 
can be accepted by all members of the company. Through the boundary system, the company builds boundaries for behaviour that may bring risks to the company in the form of code of conduct, job description, regulations and operational standards.

3. Diagnostic control is a feedback system that functions to monitor, evaluate, and appreciate the achievement of key performance areas and to correct deviations that may occur as a result of standard setting. Diagnostic control helps companies achieve their goals by focusing on resolving variances that occur.

4. Interactive control is a system used by top management to participate personally and routinely in the decision-making process carried out by its lowerrank managers. This system facilitates the learning process, knowledge management as well as vertical flow of management information which also stimulates the company in developing new ideas and strategies to control business uncertainty.

The four control systems are interdependent (Mundy, 2010) and complementary (Widener, 2007). LOC offers a broader perspective on the company's control system through the scope of the controls applied and how the company implements them (Hermawan et al., 2021). The impact of a performance-based incentive scheme on employee entrepreneurship will differ depending on the LoC (Ganbold et al., 2021). Uncertainty and strategic risk are always associated with the LOC framework. Each company faces a different level of strategic risk and uncertainty, so the implementation of LOC must be in accordance with the conditions faced by the company. When companies are in an increasingly dynamic and complex business environment, strategy implementation must be able to adapt to these conditions (Mc Adam et al., 2019).

Teece and Pisano (1994) firstly introduced dynamic capabilities as the development of a resource-based strategy which was considered not to have involved environmental change factors in its implementation. The concept of dynamic capabilities comes with an emphasis on two main aspects, namely; first, on the changing nature of the environment; second, on strategic management's critical role in adapting, integrating, and reconfiguring talents, resources, and functional competencies both internally and externally to the company's changing environment. (Teece and Pisano, 1994).

Dynamic capabilities are a framework that is able to assist managers in reconceptualizing their tasks with the loss of the role of market mechanisms in minimizing business uncertainty (Teece et al., 2016). In addition, dynamic capabilities also become a coherent framework that is able to integrate the empirical and conceptual knowledge of current companies and their solutions (Teece, 1994). As formulated, dynamic capabilities consist of three important elements, namely:

1. Sensing is the ability to recognize, develop, co-design, and appraise technological opportunities and threats in relation to customers' needs.

2. Seizing is the ability of a firm to mobilize resources both to satisfy demands, capture business prospects as well as create values from the implementation of these 
activities.

3. Transforming is the ability to make continuous updates.

Sensing, seizing and transforming become very crucial for companies to sustain in the long term with changes in customers, competitors and technology (Teece, 2007).

\subsection{Visionary Leader Competency}

A leader along with his competency plays an important role in a company's actions in the business world. Through its strategy formulation and implementation in decision making, a leader can bring the company to move forward and develop. Successful leaders can be seen from the progress, development, and innovation produced by the company they lead (Bedford, 2015). The complexity of the changing business climate increases the complexity of the business world. It forces leaders to keep taken their positions and functions into account in order to be able to adapt and integrate their new roles and responsibilities (Gilley, 2005). as an example emotional leadership, in its coaching function, can have a positive impact on an organization's culture and, as a result, increase the job satisfaction of employees who have access to critical resources that drive organizational performance (Kim \& Wee, 2020).

In her book entitled "The Manager as a Change Leader" (2005), Ann Gilley identifies 7 dimensions of leadership in a framework consisting of roles, responsibilities, and competencies. The first dimension is the visionary role which has the following responsibilities and demands for competency:

Table 1: Change Leader Visionary Role - Responsibilities \& Competencies

\begin{tabular}{|c|c|}
\hline Responsibilities & Competencies \\
\hline Quo & Risk Taker \\
& Business Knowledge \\
& Problem Solver \\
Persuasive \\
Confident \\
& Adaptable Results-driven \\
\hline Imagine the Future & Ability to Visualize \\
& Creative \\
& Tolerant of Ambiguity \\
\hline Philosophy of & Accountable \\
Stewardship & Ability to put the needs of other above his own \\
\hline Align the Change & Strategic \\
& Alliance Builder \\
\hline Share the Vision & Articulate \\
\hline Source: The Manager as a & Change Leader p.58 (2005) \\
\hline
\end{tabular}


Leaders performing visionary roles completed with competencies inherent in these roles have the ability to see the potential of how the business world will continue to develop and is ready to take steps towards the development through company performance.

\section{Hypotheses Development}

\subsection{Levers of Control dan Dynamic Capabilities}

Levers of Control allows a company to have Dynamic Capabilities to respond to uncertainties from the company's external environment (Simons, 2000). Ian McCarthy and Brian Gordon (2010) describe in general the concept of LoC linkage as a part of MCS in supporting the company's Dynamic Capabilities in a theoretical model as follows:

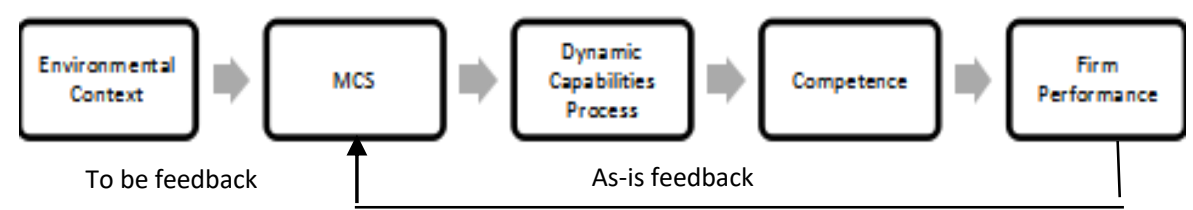

Fig. 1: Contingent management control and dynamic capabilities: a general theoretical model

The model explains that the fluctuation of environmental uncertainty condition produces different feedbacks so that it includes a different control system which in turn will encourage exploration and exploitation which is a form of the company's Dynamic Capabilities.

Therefore, the first hypothesis in this study can be formulated as follows:

H1: There is a positive effect of the implementation of Levers of Control on Dynamic Capabilities

\subsection{Levers of Control dan Visionary Leader Competency}

Some previous studies have tested the effect of LoC on leadership style. The role of a leader will clearly affect the company's performance through decision making. As concluded by Ahmadasari, et al. (2017) in their study entitled "Leadership change: a case study analysis of strategy and control system development", it is mentioned that leadership will be manifested through leader-employee interactions in control system practices. Moreover, leadership and group composition play crucial roles in improving information sharing among team members (Kim \& Bang, 2021). It becomes the novelty of the study because there has been no research that explicitly examines the correlation between LoC and leader's competency. Thus, the hypothesis can be formulated: 
$\mathrm{H} 2$ : There is a positive effect from the implementation of Levers of Control on Visionary Leader Competency

\subsection{Visionary Leader Competency and Dynamic Capabilities}

Dynamic Capabilities are related to management activities at a high-level in the form of the ability to define and then catch the chance, to anticipate risk, to combine and to transform specialized resources to deal with changing consumer needs, to maintain and to strengthen the company's evolutionary suitability as well as to create long-term value for investors. Without Dynamic Capabilities, the company's resources and competencies will only be profitable in a short term while the inventions and innovations produced often fail to capitalize on their utilization (Teece, 2007). With the suitability between the Dynamic Capabilities perspectives that are able to generate long-term profits with the competencies owned by a visionary leader role (Table 1.1). Then, the next hypothesis in this study is:

H3: There is a positive effect of the implementation of Visionary Leader Competency on Dynamic Capabilities

\subsection{Visionary Leader Competency as Intervening Variable}

The existence of LoC that is able to support the creation of Dynamic Capabilities definitely cannot be separated from the synergy formed from each component of the company. Human cognition through the competency of a leader is one of the keys to its success. The way a corporation produces, forms, and implements capabilities is determined by managerial decisions (Dosi, et al., 2008; Teece, et al., 2016). In simple terms, Teece (2016) states that managers play a role in the Dynamic Capabilities framework.

H4: Levers of Control affect Dynamic Capabilities through Visionary Leader Competency

From the literature review conducted by McCarthy and Brian Gordon (2010), they conclude that when the management control system represented by the implementation of levers of control taken by the company congruently both corporately and environmentally, the control system is an important determinant of the creation of the company's Dynamic Capabilities. This research will elaborate the study by adding the competency role of a visionary leader as a variable bridging LoC with the company's Dynamic Capabilities. 


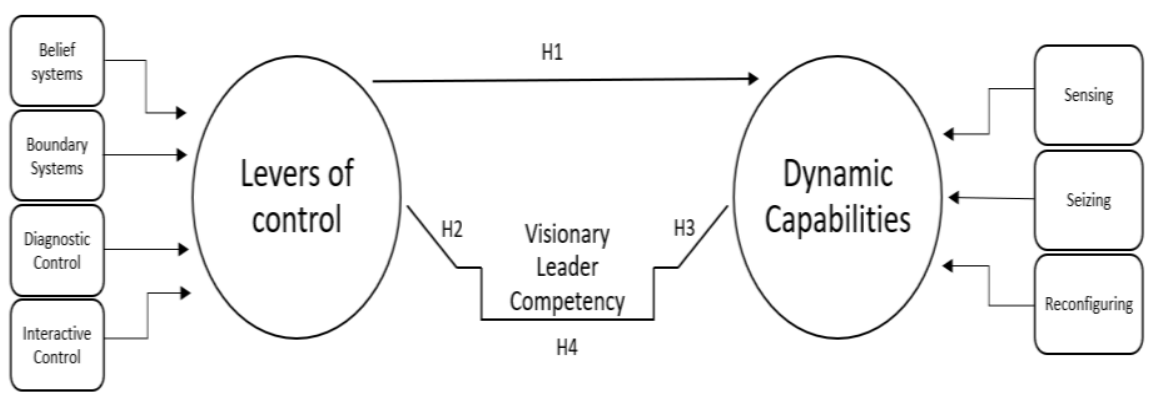

Fig. 2: Conceptual Framework

\section{Methodology}

\subsection{Sampling and Data Collection Technique}

This research was an empirical study using quantitative data analysis. The data used was primary data collected through the distribution of digital questionnaires (google form) consisting of a list of questions on respondents' perceptions of Levers of Control, Dynamic Capabilities, and also self-assessment of their visionary competencies. The target respondents were line, middle, and top management of cross-industry companies in Indonesia, both the private ones and those listed on the stock exchange.

The questions on the questionnaire were the adoption of the questionnaire regarding the perception of Levers of Control in the publication of scientific research by Hermawan, et al. (2021), the questionnaire on Dynamic Capabilities in Kaur's book (2019), and the questionnaire on the visionary leader assessment in Gilley's book (2005). To ensure that the respondent's target was met, the questionnaire was equipped with an introduction explaining the research objectives and an access of a profile of the intended respondents which could only be proceeded to the core questions of the questionnaire if it met the respondent's profile criteria required.

The distributed questionnaire collected 48 responses. Meanwhile, Cohen (1992) has provided a guide table for measuring the number of samples for the SEM-PLS model which considers the significance and the number of the largest constituents in the research construct which are as follows:

Table 2: The Guide on SEM-PLS Sample Size Determination 


\begin{tabular}{|c|c|c|c|c|c|c|c|c|c|c|c|c|}
\hline \multirow{4}{*}{$\begin{array}{l}\text { Maximum Number of } \\
\text { Arrows Pointing at a } \\
\text { Construct }\end{array}$} & \multicolumn{12}{|c|}{ Significance Level } \\
\hline & \multicolumn{4}{|c|}{$1 \%$} & \multicolumn{4}{|c|}{$5 \%$} & \multicolumn{4}{|c|}{$10 \%$} \\
\hline & \multicolumn{4}{|c|}{ Minimum $\mathrm{R}^{2}$} & \multicolumn{4}{|c|}{ Minimum $\mathrm{R}^{2}$} & \multicolumn{4}{|c|}{ Minimum $\mathrm{R}^{2}$} \\
\hline & 0.10 & 0.25 & 0.50 & 0.75 & 0.10 & 0.25 & 0.50 & 0.75 & 0.10 & 0.25 & 0.50 & 0.75 \\
\hline 2 & 158 & 75 & 47 & 38 & 110 & 52 & 33 & 26 & 88 & 41 & 26 & 21 \\
\hline 3 & 176 & 84 & 53 & 42 & 124 & 59 & 38 & 30 & 100 & 48 & 30 & 25 \\
\hline 4 & 191 & 91 & 58 & 46 & 137 & 65 & 42 & 33 & 111 & 53 & 34 & 27 \\
\hline 5 & 205 & 98 & 62 & 50 & 147 & 70 & 45 & 36 & 120 & 58 & 37 & 30 \\
\hline 6 & 217 & 103 & 66 & 53 & 157 & 75 & 48 & 39 & 128 & 62 & 40 & 32 \\
\hline 7 & 228 & 109 & 69 & 56 & 166 & 80 & 51 & 41 & 136 & 66 & 42 & 35 \\
\hline 8 & 238 & 114 & 73 & 59 & 174 & 84 & 54 & 44 & 143 & 69 & 45 & 37 \\
\hline 9 & 247 & 119 & 76 & 62 & 181 & 88 & 57 & 46 & 150 & 73 & 47 & 39 \\
\hline 10 & 256 & 123 & 79 & 64 & 189 & 91 & 59 & 48 & 156 & 76 & 49 & 41 \\
\hline
\end{tabular}

Source: Cohen (1992) in Solihin and Ratmono (2013)

If referring to the conceptual framework of this study, the number of indicators making up the largest construct was 4 (LoC indicators) so that it had an expected significance of $5 \%$ and a minimum $\mathrm{R}$ square of 0.5 . The number of samples in this study had exceeded the minimum number required in the table which is 42 . The number of responses that was relatively small collected from the distributed questionnaires was also caused by the target respondents who were the top line managers having high workload and complicated bureaucracy hampering them to allocate their time in filling out the questionnaire. The data collected as a whole had represented the respondent's profile and the series of underlying theories so that the limitation of the number of respondents was also needed to avoid data saturation. When no new code is found in the collected data, it will cause the same pile of data (Urquhart, 2013). Meanwhile, if it is reproduced and when additional data does not bring anything new from the overall data pattern that has been obtained, data saturation (saturation) can occur (Given, 2016). Based on these recommendations, this study applied a non-probability sampling method that is saturated sampling.

The data collection period was during June-August 2021 while the overall research period was during May-September 2021.

\subsection{Data Analysis}

This research used SMART PLS 3.2.1 software. It applied to small sample sizes and ensured a normal distribution of the data. First, this research conducted a preliminary analysis to check the data accuracy to be used when examining the PLS model. Second, its validity of such conceded model was followed by a hypothesis testing analysis to determine the validity of the constructs.

In the use of SEM-PLS, the value of construct validity will be measured. The AVE value indicates convergent validity, which is measured using the loading 
factor. The indicators in a value range of $0.4-0.7$ will be considered to be used by measuring the impact on the AVE value and Composite Reliability. The indicators with a value above 0.7 will be used immediately (Hair et al, 2014). Based on Sholihin and Ratmoko (2013), for the AVE value, the threshold set is 0.5 . The discriminant validity of a construct is assessed by comparing its AVE root to the correlation value between the latent variables, which must be greater (Sholihin and Ratmoko, 2013). Cronbach's alpha and Composite Reliability coefficients were used as benchmarks for reliability testing. Values above 0.8 are considered to be reliable, while those between 0.6 and 0.7 are thought to be quite reliable, and those below 0.5 are considered to be unreliable (Hair, et al., 2014). The p value (significance level) of the indicators, ARS (0.05), AVIF (5) and APC (0.05), were also used to perform the model fit test (Sholihin and Ratmoko, 2013).

The structural model testing (inner model) is used to forecast the structural model's relational relationships (Hartono, 2016). There are five phases to evaluating structural models (Hair et al., 2014): assessment of collinearity, coefficient of structural model path, coefficient of determination (R2), effect size (f2), and predictive relevance $(\mathrm{Q} 2)$. In this analysis, the $\mathrm{p}$ value was set at $5 \%$.

\section{Results}

\subsection{Validity and Reliability Test}

The measurement model analysis (outer model) in this study was carried out using validity and reliability tests. Convergent and discriminating validity are two types of validity tests. In the meantime, the reliability test is specified in the Composite Reliability and Cronbach's Alpha value calculations. The discriminant validity test yielded the loading factors are above 0.70 . However, there are some indicators that are still below 0.70 and must be eliminated so that all indicators meet the requirements of convergent validity and have the validity required by the rule of thumb.

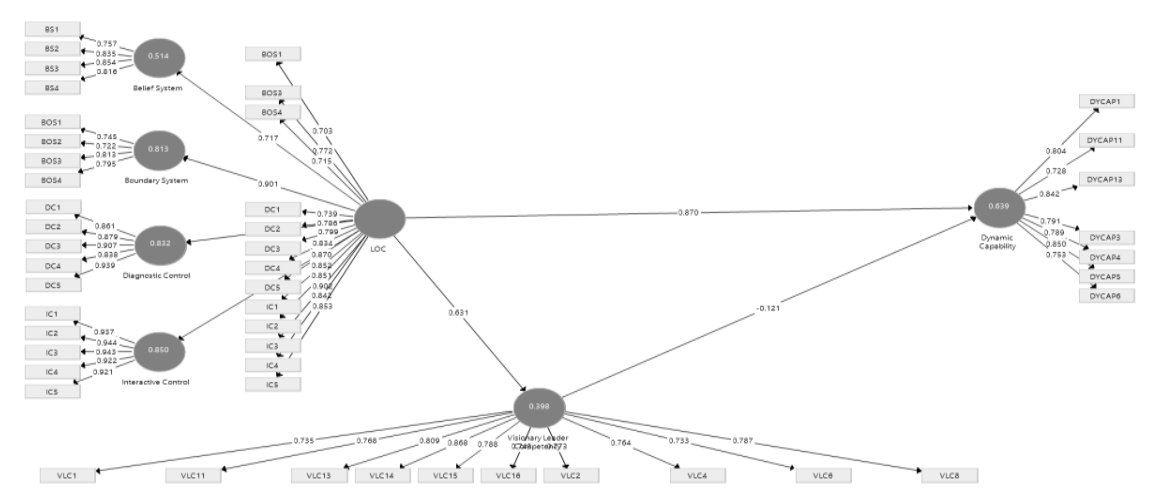

Fig. 3: Construct Model 
The next analysis after the validity test is the reliability test. Composite Reliability and Cronbach's Alpha are two different metrics used in the reliability test. If the Composite Reliability rating is greater than 0.7 and Cronbach's Alpha is greater than 0.6 , a construct is considered reliable. The Validity Scales results for each variable are as follows:

Table 3: The Validity and Reliability Test Results

\begin{tabular}{|c|c|c|}
\hline VAR & $\boldsymbol{\alpha}$ & $\begin{array}{c}\text { Comp, } \\
\text { Reliabiliy }\end{array}$ \\
\hline Levers of Control & 0.956 & 0.961 \\
\hline Visionary Leader Competency & 0.927 & 0.939 \\
\hline Dynamic Capability & 0.903 & 0.923 \\
\hline
\end{tabular}

Source: data processing

The results of the Composite Reliability and Cronbach's Alpha measurements show that all variables for Composite Reliability have a value of 0.70 and all variables for Cronbach have a value above 0.60 . Thus, these results can be declared valid and have a fairly high reliability.

\subsection{Hypothesis Testing}

Based on the test using SMART PLS 3.2.1 software, obtained results are as follows:

Table 4: The Test Results of Direct Effect Hypothesis

\begin{tabular}{|c|c|c|c|c|c|c|}
\hline $\begin{array}{c}\text { Hypot } \\
\text { hesis }\end{array}$ & Variable Relationship & $\begin{array}{c}\text { Esti } \\
\text { mate }\end{array}$ & SE & CR & P & Conclusion \\
\hline 1 & $\begin{array}{c}\text { There is a positive impact } \\
\text { of the LoC application on } \\
\text { the Dynamic Capabilities }\end{array}$ & 0.874 & 0.081 & 10,682 & 0.000 & Accepted \\
\hline 2 & $\begin{array}{c}\text { There is a positive impact } \\
\text { of the LoC application on } \\
\text { the Visionary Leader } \\
\text { Competency }\end{array}$ & 0.654 & 0.080 & 7.908 & 0.000 & Accepted \\
\hline 3 & $\begin{array}{c}\text { There is a positive effect of } \\
\text { the Visionary Leader } \\
\text { Competency application } \\
\text { on the Dynamic } \\
\text { Capabilities }\end{array}$ & 0.113 & 0.113 & 1.066 & 0.287 & Rejected \\
\hline
\end{tabular}

Source: data processing.

H1: There is a positive effect of the LoC application on the Dynamic Capabilities

As shown on the table 4, the estimated coefficient number is 0.874 which is the effect of LoC on Dynamic Capabilities, with value standard error (SE) of 0.081 and the value of critical ratio $(\mathrm{CR})$ which is the $t$ count $>$ of the $t$ table of $10.682>1.96$, or with a significant level of $\mathrm{P}<$ alpha value which is $0.000<0.05$. Thus, it can be 
stated that there is a positive impact of the LoC application on the Dynamic Capabilities in the managerial of line, middle and upper level in cross industry. Therefore, this hypothesis is accepted.

$\mathrm{H} 2$ : There is a positive effect of the Levers of Control application on the Visionary Leader Competency

Based on the table 4, the estimated coefficient number is 0.654 which is the effect of Levers of Control on Visionary Leader Competencies, with value standard error (SE) of 0.080 and the value of critical ratio (CR) which is the $t$ count $>$ of the $t$ table of $7.908>1.96$, or with a significant level of $\mathrm{P}<$ alpha value which is $0.000<0.05$. Thus, it can be stated that there is a positive impact of the LoC application on the Visionary Leader Competency in the managerial of line, middle and upper level in cross industry. Therefore, this hypothesis is accepted.

H3: There is a positive effect of the Visionary Leader Competency application on the Dynamic Capabilities

As shown on the table 4 above, the estimate coefficient number is -0.113 which is the effect of Visionary Leader Competency on Dynamic Capabilities, with value standard error (SE) of 0.113 and the value of critical ratio (CR) which is the $t$ count $>$ of the t table of $1.066<1.96$, or with a significant level of $\mathrm{P}<$ alpha value which is $0.287>0.05$. Thus, it can be stated that there is no positive impact of the LoC application on the Dynamic Capabilities in the managerial of line, middle and upper level in cross industry. Therefore, this hypothesis is rejected.

The testing of hypothesis 4 on the mediating effect of Visionary Leader Competency results in:

Table 5: The Test Results of the Indirect Effect Hypothesis (Mediation)

\begin{tabular}{|c|c|c|c|c|c|c|c|}
\hline H & $\begin{array}{c}\text { Variable } \\
\text { Relationship }\end{array}$ & $\begin{array}{c}\text { Ori } \\
\text { Sample }\end{array}$ & (M) & $\begin{array}{c}\text { (STDE } \\
\text { V) }\end{array}$ & T Stats & P Value & Concl \\
\hline 4 & $\begin{array}{c}\text { Levers of Control } \\
\text { affecting Dynamic } \\
\text { Capabilities through } \\
\text { Visionary Leader } \\
\text { Competency }\end{array}$ & -0.076 & -0.077 & 0.074 & 1.025 & 0.306 & Rejected \\
& & & & & \\
\hline
\end{tabular}

Source: data processing.

H4: Levers of Control affecting Dynamic Capabilities through Visionary Leader Competency

Based on the calculation using bootstrap, in which the results of the estimation coefficient test of Levers of Control on Dynamic Capabilities through Visionary Leader Competency are -0.077 with a t value of 1.025 and a standard deviation of 0.074 , the $\mathrm{p}$ value is $0.306>0.05$. Therefore, the hypothesis is rejected. 


\section{Discussion}

This analysis aims to carry out the role of the visionary leader's competency in bridging the effect of Levers of Control on the company's Dynamic Capabilities. To fulfill this objective, this study builds 4 hypotheses whose test results have been described in the previous section.

The testing of the first hypothesis has shown that LoC has a major direct impact on Dynamic Capabilities. These findings support previous studies conducted by Ian McCarthy and Brian Gordon (2010). Belief system shape corporate goals by defining strategic opportunities' domain and creating a broad framework for defining corporate identity and action. It helps companies spread expectations and establish a uniform mission to continuously seek opportunities based on the company's strategy (Widener. 2007). Boundary system is likened to a "brake" for the company (Simon, 1995), which helps the company retain and focus employees to ensure that there are no continuous deviations from predetermined standards. It includes rules, regulations, codes of conduct, and operating directives that effectively limit the strategic opportunities that are not the company's goals and are also the domain of acceptable activities for the company. Diagnostic control, besides being able to encourage performance through feedback, it is also believed to be able to identify discrepancies in the company's behavior and then adjust them again. This system is important in supporting the execution of the company's strategy and ensuring the company carries out the right activities as well as possible. Whereas Interactive control helps companies build an understanding of current or existing strategic uncertainties. This system provides an overview of the company's external conditions that allow the company to find and better grasp its information climate, cut back the feedback cycle, also even become able to influence its environment. Interactive control opens the company's mindset to provide opportunities for the growth of innovation and creativity, which in other words has supported the formation of knowledge-based dynamic capabilities.

There are at least 2 strategic implications of accepting this H1. First, companies must strengthen LoC and insert agility in it as a counterweight to current business dynamics. Second, in every decision aimed at building Dynamic Capabilities, the company has involved harmonization with the implementation of LoC so that its implementation always goes hand in hand and spurs the expected results.

The second and third hypotheses are tests that bring novelty in this study. There has been no previous research that specifically tested the effect of LoC on Visionary Leader Competency (H2) and between Visionary Leader Competency on the company's Dynamic Capabilities (H3). Statistical testing of hypothesis 2 validates the effect of LoC on Visionary Leader Competency. This finding can be an illustration for the company of the increasingly crucial process of preparing the company's LoC. With a strong LoC, the leader's visionary competency will be 
encouraged to improve, and vice versa. In the meantime, the testing results of the hypothesis 3 is inconsistent with the research results done by Xin, et., al (2020) and Helfat, et al. (2007) who examined the positive relationship of leadership style, in which there is an element of the leader's visionary nature on the company's Dynamic Capabilities. The two studies as described in the introduction of this study have proven that there is a positive effect in between the tested variables. This is presumably due to the application of a leadership style in which a leader is a set of competencies and other elements that are complementary and interdependent so that visionary competency becomes a variable that has negative value if it stands alone.

The results of the $\mathrm{H} 3$ test have a major effect on the $\mathrm{H} 4$ testing stage which is the main hypothesis in this study. The $\mathrm{H} 4$ test consistently produces findings that the relationship between LoC and the company's Dynamic Capabilities is not mediated by Visionary Leader Competency. The statistical test scores presented in the previous session indicate that companies should expand the focus on developing leadership skills not only on certain competencies such as visionary competencies. More importantly, if the company does not yet have a core value that is clearly declared and defined for all employees, the company will really need a management line with strong leadership (Hermawan, et al., 2021). Another assumption is that Visionary Leader Competency has emphasis on how to direct company performance and long-term capabilities, whereas Dynamic Capabilities requires focus on the business dynamics which sometimes quick decision needs to be made in a short period of time (short-term).

\section{Conclusion}

In addition to the main objective, which is to see the role of visionary leader competency in bridging the relationship between LoC and the company's Dynamic Capabilities, this study also examines the relationship between related variables that contribute to answering the current research gap. Tests on the direct relationship between LoC and the company's Dynamic Capabilities empirically show a positive and significant effect. These results will strengthen the contingent management control and dynamic capabilities' general theoretical model compiled by Ian McCarthy and Brian Gordon (2010) which have not been supported by statistical test results. Likewise, subsequent tests revealed there was a favourable and significant relationship between LoC and visionary leadership capability. It will add newness that complements previous research on the relationship between LoC and leadership style. Furthermore, testing of the third hypothesis shows that there is no positive and significant effect of visionary leader competency on Dynamic Capabilities which consistently leads to the results of testing the main hypothesis in this study. In other words, there is no mediating effect of visionary leader competency on the relationship between LoC and the company's Dynamic Capabilities. 
The findings in this study complement the existing literacy and become the basis for consideration of the company's strategic decision making. LoC development becomes very important considering its direct influence on the company's Dynamic Capabilities as well as the specific competencies of leaders as decision makers. With a strong LoC properly understood by all levels of the organization and can be implemented optimally, the company will get multiplied benefits both from the development of HR competencies and overall company capabilities. Regarding the lack of influence of visionary leader competency either directly on dynamic capabilities or as a mediating role, it is crucial to have a strong visionary competency. However, this competency shall be combined with other competencies in a specific leadership style in order to support quick decision making and to face business dynamics which are full of risks and uncertainties.

On a broader scale, the results of this study can help industry players in the process of supporting the economic transformation of a country that is in the Middle-Income Trap (MTI) to be able to leave and enter the developed country group. If every company in a country is able to build its Dynamic Capabilities by understanding the supporting factors and those that need to be avoided in the process of preparing its strategic steps, it will simplify and minimize the failure costs that must be borne by the company in achieving its goals. Dynamic Capabilities are still the main requirement for companies to have in the ongoing disruption and its increasing impact on the business world.

This research is limited to research samples taken within the scope of the territory of Indonesia, the number of samples is relatively small, as well as simple research methods with research variables that can still be developed. These limitations can be a trigger for further research, including increasing the number of samples, comparing conditions in several countries, combining several research methods with more complex research variables so as to produce different findings and enrich literacy.

\section{References}

Adi and Sukmawati. (2020). The effect of levers of control and leadership style on creativity. Journal of Indonesian Economy and Business, 35(3), https://doi.org/10.22146/jieb.55466.236-256.

Akkaya, Bulent. (2020). Review of leadership styles in perspective of dynamic capabilities: an empirical research on managers in manufacturing firms. Journal of Administrative Science, 18(36), https://doi.org/10.35408/comuybd.681427. 389-407. 
Baird, K., Su, S. And Munir, R. (2019). Levers of control, management innovation and organisational performance. Pacific Accounting Review, 31(3), Https://doi.org/10.1108/PAR-03-2018-0027. 358-375.

Bedford, D. S. (2015). Management control systems across different modes of innova-tion: Implications for firm performance. Management Accounting Research, 28, https://doi.org/10.1016/j.mar.2015.04.003.12-30.

Ganbold, G., Chen, C., Ayaz, M., \& Jang, H. (2021). The Impact of Incentive System on Employees' Entrepreneurship and Innovation Performance: Moderating Effect of Locus of Control. Journal of System and Management Sciences, 11 (3), https://doi.org/10.33168/JSMS.2021.0303.41-57.

Gilley, A. (2005). The manager as change leader. Westport, CT: Praeger.

Given. L.M. (2016). 100 Questions (and Answers) About Qualitative Research. Sage, Thousand Oaks.

Hair, J., Hult, G. T. M., Ringle, C., \& Sartstedt, M. (2014). A primer on partial least square structural equation modelling (PLS-SEM). Los Angeles: Sage.

Hartono, J. (2016). Konsep dan aplikasi PLS (Partial Least Square) untukpenelitianempi-ris. EdisiPertama [The concept and applica-tion PLS (Partial Least Square) for empiri-cal research]. Yogyakarta: BPFE.

Kaur, Vaneet. (2019). Knowledge-based dynamic capabilities the road ahead in gaining organizational competitiveness. Springer.

Hermawan, A., Bachtiar, E., Wicaksono, P., \& Sari, N. (2021). Levers of control and managerial performance: the importance of belief systems. Gadjah Mada International Journal of Business, 23(3), Https://doi.org/10.22146/gamaijb.62612. 237-261.

Kim, B., \& Bang, H. 2021. When Do We Share Our Knowledge to Others? Journal of Logistics, Informatics and Service Science, 8(1), https://doi.org/10.33168/LISS.2021.0104. 51-66.

Kim, S., \& Wee, K.. (2020). Effect of Self-Awareness and Self-Management on Organizational Atmosphere, Job Satisfaction as Leadership Coaching Roles. Journal of System and Management Sciences, 10 (1), https://doi.org/10.33168/JSMS.2020.0103.51-61. 
Klingebiel, R., \& Lange, D. (2010). Strategic reconfigurations: building dynamic capabilities in rapid innovation -based industries. Edward Elgar.

Kruis, A. M., Spekl, R. F., \& Widener, S. K. (2016). The levers of control framework: an exploratory analysis of balance. Management Accounting Research, 32, Https://doi.org/10.1016/j.mar.2015.12.002. 27-44.

Liang, X., Xiu, L., Fang, W. And Wu, S. (2020). How did a local guerrilla turn into a global gorilla? Learning how transformational change happened under dynamic capabilities from the rise of huawei. Journal of Organizational Change Management, 33(2), Https://doi.org/10.1108/JOCM-09-2018-0246. 401-414.

Lopez-Cabrales, A., Bornay-Barrachina, M. And Diaz-Fernandez, M. (2017). Leadership and dynamic capabilities: the role of hr systems. Personnel Review, 46(2), Https://doi.org/10.1108/PR-05-2015-0146. 255-276.

Mcadam, R., Miller, K., \& mcsorley, C. (2019). Towards a contingency theory perspective of quality management in enabling strategic alignment. International Journal of Production Economics, 207, Https://doi.org/10.1016/j.ijpe.2016.07.003. 195-209.

McCarthy, I \& Gordon, B. (2010). Leveraging dynamic capabilities: a contingent management control system approach. [w:] S. Wall, C. Zimmermann, R. Klingebiel, D. Lange (eds.), Strategic Configurations. Building Dynamic Capabilities in Rapid Innovation-Based Industries. Edward Elgar, Cheltenham, s. 13-32.

Miftah, F., \& Hermawan, Pri. (2021). A Service Dominant Logic - based Crisis Management: Collaborative, Dynamic, Iterative, and Holistic. Journal of Logistics, Informatics and Service Science, 8(1), https://doi.org/10.33168/LISS.2021.0107. $100-116$.

Mohamud, M. And Sarpong, D. (2016). Dynamic capabilities: towards an organizing framework. Journal of Strategy and Management, 9(4), Https://doi.org/10.1108/JSMA-11-2015-0088. 511-526.

Saunders, B., Sim, J., Kingstone, T. et al. (2018). Saturation in qualitative research: exploring its conceptualization and operationalization. Qual Quant, 52, https://doi.org/10.1007/s11135-017-0574-8. 1893-1907. 
Sholihin, M., \& Ratmono, D. (2013). Analisis SEM-PLS dengan WarpPLS 3.0 untuk hubungan non linier dalam penelitian sosial dan bisnis. Yogyakarta: Penerbit Andi

Simons, R. (1995). Levers of control: how managers use innovative control systems to drive strategic renewal. Boston, MA: Harvard Business School Press.

Speklé, R. F., van Elten, H. J., \& Widener, S. K. (2017). CREATIVITY AND CONTROL: A PARADOX-EVIDENCE FROM THE LEVERS OF CONTROL FRAME-WORK. Behavioral Research in Accounting, 29(2), Https://doi.org/10.2308/bria-51759. 73-96.

Teece, D. J. \& Pisano, G. (1994). the dynamic capabilities of firms: an introduction. Industrial and corporate change, 3(3), https://doi.org/10.1093/icc/3.3.537-a. 537556 .

Teece, D. J., Pisano, G., \& Shuen, A. (1997). Dynamic capabilities and strategic management. Strategic Management Journal, 18(7), Https://doi.org/10.1002/(SICI)1097-0266(199708)18:7<509::AID SMJ882>3.0.CO;2-Z. 509-533.

Teece, D. J. (2007). Explicating dynamic capabilities: the nature and microfoundations of (sustainable) enterprise performance. Strategic Management Journal, 28, Https://doi.org/10.1002/smj.640. 1319-1350.

Teece, D., Peteraf, M., \& Leih, S. (2016). Dynamic capabilities and organizational agility: risk, uncertainty, and strategy in the innovation economy. California Management Review, 58(4), Https://doi.org/10.1525/cmr.2016.58.4.13. 13-35.

Urquhart, C. (2013). Grounded Theory for Qualitative Research: A Practical Guide. Sage, Thousand Oaks.

Widyaningdyah, A. (2020). Levers of control dan keunggulan bersaing: apakah pengendalian manajemen sebuah sistem?. Media Riset Akuntansi, Auditing \& Informasi, 20(2), 221-246. 